\title{
Regulation of C-myc Expression during Growth and Differentiation of Normal and Leukemic Human Myeloid Progenitor Cells
}

\author{
Shantharaj D. Gowda, Robert D. Koler, and Grover C. Bagby, Jr. \\ Department of Medical Genetics, Oregon Health Sciences University, and Department of Medicine, Division of Hematology and Medical \\ Oncology, Oregon Health Sciences University and Veterans Administration Medical Center, Portland, Oregon 97201
}

\begin{abstract}
C-myc proto-oncogene transcripts from serially harvested, colony-stimulating activity (CSA)-stimulated, normal progenitorenriched human bone marrow cells were compared to those of the promyelocytic leukemia cell line HL-60 and to those of freshly obtained human myeloid leukemic cells. During the early culture period both normal and leukemic cells expressed the cmyc oncogene. In normal cells maximal expression occurred after $24 \mathrm{~h}$ of culture and did not occur in the absence of CSA. At this time, progranulocytes predominated in the cultured cells. Although cellular proliferation occurred for $96 \mathrm{~h}$ in vitro, c-myc expression ceased after 24-36 h. Terminally differentiated cells predominated in these cultures by $120 \mathrm{~h}$. In contrast, although leukemic cells also expressed c-myc in vitro, transcription persisted throughout the culture period and, in the case of HL-60 cells, occurred in the absence of exogenous CSA. We also noted that normal cells with only one diploid gene copy exhibited, after $24 \mathrm{~h}$ of culture, only twofold fewer transcripts than did HL-60 cells in which there were 16 myc copies. Furthermore, c-myc mRNA degradation rates were similar in normal cells and in HL-60 cells. We conclude that c-myc transcription is a normal event in granulopoiesis linked to proliferative activity as well as to primitive developmental stage. Furthermore, the most consistent abnormality in leukemic cells in vitro is their failure to suppress transcriptional activity of this gene. We suggest that c-myc transcription in HL-60 cells may be appropriate for cells arrested at that developmental stage and that the amplified genes in HL-60 cells are quiescent relative to c-myc in normal cells at the same differentiation stage. The techniques described herein may be of value in identifying mechanisms by which normal hematopoietic cells suppress c-myc expression and aberrancies of these mechanisms in leukemic cells.
\end{abstract}

\section{Introduction}

Retroviral genes that induce infected cells to exhibit the neoplastic phenotype are known as viral oncogenes $(v-o n c)^{1}(1,2)$.

Portions of this work were presented at the annual meeting of the American Society of Hematology, Miami, in 1984, and were published in abstract form for this meeting.

Received for publication 6 June 1985 and in revised form 29 July 1985.

1. Abbreviations used in this paper: c-onc, cellular oncogene; CSA, colonystimulating activity; HPCM, human placental conditioned medium; LDBM, low density bone marrow; v-onc, viral oncogene.

J. Clin. Invest.

(c) The American Society for Clinical Investigation, Inc.

0021-9738/86/01/0271/08 \$1.00

Volume 77, January 1986, 271-278
Strong evidence supports the notion that v-onc derive from viral transduction of cellular sequences, currently known as cellular oncogenes (c-onc) or proto-oncogenes $(1,2)$. That c-onc have been conserved throughout evolution suggests that they serve critical functions in normal cells $(1,2)$. Recent evidence suggests that these functions are related to cellular growth and differentiation. For example, viral oncogenes directly or indirectly interfere with normal cellular proliferation and differentiation (13). Moreover, certain of these genes code for either growth factors or growth factor receptors $(4,5)$. In addition, it is also clear that some c-onc are legitimately expressed in certain normal cells. For example, recent studies in mice have indicated that certain cellular oncogenes, including c-myc, are expressed during normal embryogenesis (3), and during hepatocellular (6), erythroid (7), fibroblast $(8)$, lymphoid $(8,9)$, and placental $(10)$ cell proliferation. Reconciliation of the oncogenic potential of v-onc sequences with the knowledge that their cellular homologues can be actively transcribed in normal cells is critical to our understanding of the function of cellular proto-oncogenes in normal and neoplastic cells.

C-myc is the cellular homologue of the transforming gene of avian myelocytomatosis virus, encodes two nuclear binding proteins (11), and represents one of the most widely studied of the cellular oncogenes. In part because c-myc is transcribed in certain normal proliferating cells and because experimental cmyc activation has proved to be inadequate to induce neoplasia either in vitro (12) or in vivo (13), gene expression per se is clearly insufficient to account for carcinogenesis. Consequently, an often-cited hypothesis for the involvement of c-myc in carcinogenesis is that in neoplastic cells c-myc expression is abnormally regulated $(1,14,15)$. Deregulation of c-myc activity has been attributed to chromosomal translocation (15-17) and to gene amplification $(18,19)$ either of which might account for loss of responsiveness to regulators of gene expression (3).

To determine whether c-myc expression is, in fact, inappropriate in a malignant cell requires studies on c-myc expression in normal cells $(6,8,20)$. A major stumbling block in this regard has been that malignant cells are almost always arrested at a single primitive stage of cell differentiation and normal cells are not. Comparisons of the activity of c-onc transcription in leukemic cells (a homogeneous population of primitive forms) to that of unfractionated normal marrow cells (a heterogeneous population of largely mature forms) might be misleading if the gene is transcribed only in the most primitive of those normal cells. That this might be the case is suggested by previous studies that used a variety of hematopoietic cell lines, in which c-myc was expressed in primitive cells but to a lesser extent in more mature ones (21).

Accordingly, to test the hypothesis that c-myc is constitutively expressed in replicating normal human hematopoietic cells, we used northern and dot-blot analysis to measure c-myc transcripts in serially harvested, colony-stimulating activity (CSA)-stimu- 
lated normal bone marrow cells enriched for primitive myeloid progenitors cells. We found that the number of c-myc transcripts in normal cells is high after $24 \mathrm{~h}$ of culture at which time blasts and progranulocytes predominated. At the time of maximal expression, transcript numbers were approximately the same in normal cells as in HL-60, but after 24-36 h normal cells repressed myc expression whereas leukemic cells did not. Because transcript degradation rates were high in both normal and leukemic cells, we conclude that the myc expression in cultured normal and leukemic cells differs in that gene transcription is not appropriately repressed in the latter.

\section{Methods}

Enrichment of bone marrow for progenitor cells. Bone marrow cell samples were obtained after informed consent from paid normal volunteers. Low density bone marrow (LDBM) cells were prepared with Ficoll-Paque centrifugation (22). $T$ lymphocytes were removed by E-rosette depletion $(23,24)$. Adherent cells were removed sequentially on three nylon fiber columns (25) followed by adherence to serum-coated dishes (26). Nonadherent LDBM cells were then cultured for $96 \mathrm{~h}$ in complete medium with $10 \%$ human placental conditioned medium (HPCM) prepared according to the method of Schlunk and Schleyer (27). The colony growth efficiency of these cells in colony-forming unit/granulocyte-macrophage assays was $2-3 \%$. Cloning efficiency (colonies [ 240 cells/aggregate] plus clusters and microclusters [ $2-40$ cells/aggregate]) had a range of $8-22 \%$.

Surface marker analysis. $1 \times 10^{6}$ cells in $200 \mu$ l of RPMI (Gibco, Grand Island, NY) were incubated with $5 \mu$ l of OKM1 (Ortho Diagnostics, Inc., Raritan, NJ) or OKT3 (Ortho Diagnostics, Inc.) monoclonal antibodies separately for $30 \mathrm{~min}$ on ice. At the end of the incubation period, cells were washed twice and resuspended in $200 \mu \mathrm{l}$ of RPMI. The cells were then incubated for $30 \mathrm{~min}$ on ice with $50 \mu \mathrm{l}$ of 1:30 dilution of fluorescein-conjugated goat anti-mouse immunoglobulin (Cooper Biomedicals, Malvern, PA). The cells were washed twice and resuspended in RPMI containing $10 \%$ heat-inactivated fetal calf serum and $2 \%$ formaldehyde. The cells incubated without the first antibody were used as controls. Fluorescence sensitivity was assessed using an Ortho $50 \mathrm{H}$ cytofluorometric sorting device (Ortho Diagnostics, Inc.).

Cell proliferation. The proliferative response to HPCM of LDBM cells was assayed by exposure of sequentially harvested cells to $5 \mu \mathrm{Ci}$ of $\left[{ }^{3} \mathrm{H}\right]$ thymidine for $30 \mathrm{~min}$. The cells were harvested onto the filters using an automatic cell harvester and air-dried. The incorporation of radioactivity was determined by liquid scintillation counting.

RNA extraction. Total RNA was isolated from cells by the procedure described by Maniatis et al. (28) utilizing the hot saturated phenol modification. Poly (A)-containing RNA was selected by oligo deoxythymidinecellulose chromatography (29). RNA was loaded using $0.5 \mathrm{M} \mathrm{NaCl}, 50$ mM Tris-Cl (pH 7.5), 1 mM EDTA, and the bound RNA was eluted off the column using diethylpyrocarbonate treated water. The concentration of poly (A)-containing RNA was determined by optical density (OD) at $260 \mathrm{~nm}$.

Northern and dot-blot analysis. For Northern blot analysis, poly (A)containing RNA was adjusted to $0.5 \mathrm{M}$ glyoxal (deionized), $50 \%$ dimethyl sulfoxide, $15 \mathrm{mM}$ sodium phosphate buffer $\left(\mathrm{pH} \mathrm{6.5)}\right.$, heated at $50^{\circ} \mathrm{C}$ for $1 \mathrm{~h}$, and subjected to electrophoresis in $1 \%$ agarose, phosphate buffer (pH 6.5) slab gels. The running buffer was $15 \mathrm{mM}$ phosphate buffer $(\mathrm{pH}$ 6.5); electrophoresis was at $1.6 \mathrm{~V} / \mathrm{cm}$ for $9 \mathrm{~h}$ with constant buffer recirculation. The RNA was transferred to Genescreen membrane (New England Nuclear, Boston, MA) by the capillary blot procedure using 25 mM phosphate buffer (pH 6.5).

For dot-blot analysis, poly (A)-containing RNA was dissolved in diethylpyrocarbonate-treated water, diluted to desired concentrations, boiled, quick-cooled on ice, and applied with gentle suction to a 4-mm diam spot on Genescreen membrane which previously had been equilibrated with $2 \times$ SSC (1.0× SSC is $0.15 \mathrm{M}$ sodium chloride, $0.015 \mathrm{M}$ sodium citrate) supported on a no. 470 paper employing 96-hole minifold apparatus. After baking for $4 \mathrm{~h}$ at $80^{\circ} \mathrm{C}$, the blots were prehybridized over night at $42-45^{\circ} \mathrm{C}$ in a buffer containing $50 \%$ formamide (deionized), $0.2 \%$ polyvinyl pyrrolidone ( $\mathrm{mol}$ wt 40,000 ), $0.2 \%$ bovine serum albumin, $0.2 \%$ Ficoll (mol wt 400,000), $0.05 \mathrm{M}$ Tris- $\mathrm{HCl}$ (pH 7.5), $1.0 \mathrm{M} \mathrm{NaCl}$, $0.1 \%$ sodium pyrophosphate, $1.0 \%$ sodium dodecyl sulfate (SDS), $10 \%$ dextran sulfate (mol wt 500,000), and denatured salmon sperm DNA $(150 \mu \mathrm{g} / \mathrm{ml})$. Subsequently, the blots were hybridized for $24 \mathrm{~h}$ at $42-$ $45^{\circ} \mathrm{C}$ with $7.5 \times 10^{5} \mathrm{dpm}$ of nick-translated probe per milliliter of hybridization buffer (same composition as prehybridization buffer). After hybridization, the blots were washed twice with $2 \times$ SSC at room temperature ( 5 min each wash), twice with $2 \times \mathrm{SSC}$ and $1.0 \%$ SDS at $65^{\circ} \mathrm{C}$ (30 min each wash), and finally two times with $0.1 \times \mathrm{SSC}$ at room temperature $\left(30 \mathrm{~min}\right.$ each). The membrane was dried at $22^{\circ} \mathrm{C}$ and exposed to x-ray films (X-omat AR5, Eastman Kodak Co., Rochester, NY) with an intensifying screen at $-70^{\circ} \mathrm{C}$ for $96 \mathrm{~h}$. The dot-blot autoradiogram shown was evaluated by quick-scan densitometer (Helena Laboratories, Beaumont, TX).

DNA for dot-blotting was isolated from HPCM-stimulated LDBM cells and HL-60 cells according to the method described by Meinkoth and Wahl (30). The DNA was then dotted onto Genescreen-plus membrane (New England Nuclear), baked, and hybridized with a c-mycspecific probe as described above.

Estimation mRNA degradation rates. Total cellular RNA was extracted from LDBM cells and HL-60 cells at various times after treatment with actinomycin $D(5-10 \mu \mathrm{g} / \mathrm{ml})$ to block essentially all transcriptional activity (31). Each sample was dot-blotted onto a Genescreen membrane as described above, and analyzed for its c-myc and $\gamma$-actin mRNA content. The c-myc and $\gamma$-actin mRNA contents were analyzed and evaluated by quick-scan densitometer as described above. The intensities obtained for zero time controls and actinomycin D-treated samples were used to calculate the proportion of the c-myc or $\gamma$-actin mRNA remaining.

Four studies were performed using HL-60 cells and three using normal cells. Time-matched controls in HL-60 cells (cells to which medium rather than actinomycin $D$ was added) showed stable transcript numbers at all time points but in the normal cells transcript levels sometimes increased early in culture. Accordingly, we have chosen to express our results as the percentage of mRNA remaining using zero time transcript levels as $100 \%$.

Hybridization probes. The recombinant plasmids pRyc7.4 (kindly provided by Dr. G. Rovera, The Wistar Institute, Philadelphia, PA), pHF A-3'UT (kindly provided by Dr. L. Kedes, V.A. Medical Center, Palo Alto, CA), and pHB-1S (kindly provided by Dr. T. Maniatis, Harvard University, Boston, MA) were used as c-myc, $\gamma$-actin, and $\beta$-globin hybridization probes, respectively. These plasmids were nick-translated using nick-translation kits (Bethesda Research Laboratories, Gaithersburg, MD) and $\left[{ }^{32} \mathrm{P}\right] \mathrm{dCTP}(800 \mathrm{Ci} / \mathrm{mmol}$, New England Nuclear). The specific activity of the probes was $1-2 \times 10^{8} \mathrm{dpm} / \mu \mathrm{g}$ DNA.

\section{Results}

HPCM specifically stimulates the expansion of myeloid lineage. LDBM cells depleted of T and B lymphocytes and mononuclear phagocytes contained lymphoid-appearing cells and granulocyte precursors no more differentiated than myeloblasts. As shown in Fig. $1 a$, the majority were lymphoid in appearance but were surface immunoglobulin-, OKT3- (which recognizes T lymphocytes), and OKM1- (which recognizes monocytes and granulocytes) negative. These cells were cultured with $10 \%$ HPCM, a potent source of CSA (32), for a period of $96 \mathrm{~h}$. The cells undergo differentiation to progranulocytes by $24 \mathrm{~h}$ (Fig. $1 \mathrm{~b}$ ) and reach nonproliferative stages, namely metamyelocytes, and bands by 96-h (Fig. 1 c). Cells were regularly harvested during the period of culture for morphologic studies, analysis of $\left[{ }^{3} \mathrm{H}\right]$ thymidine incorporation, surface phenotype analysis with monoclonal antibodies, and studies of c-myc expression and gene copy number using a labeled c-myc probe.

As shown in Fig. 2, the cells cultured in the presence of HPCM revealed a progressive increase in [ $\left.{ }^{3} 3\right]$ thymidine uptake 

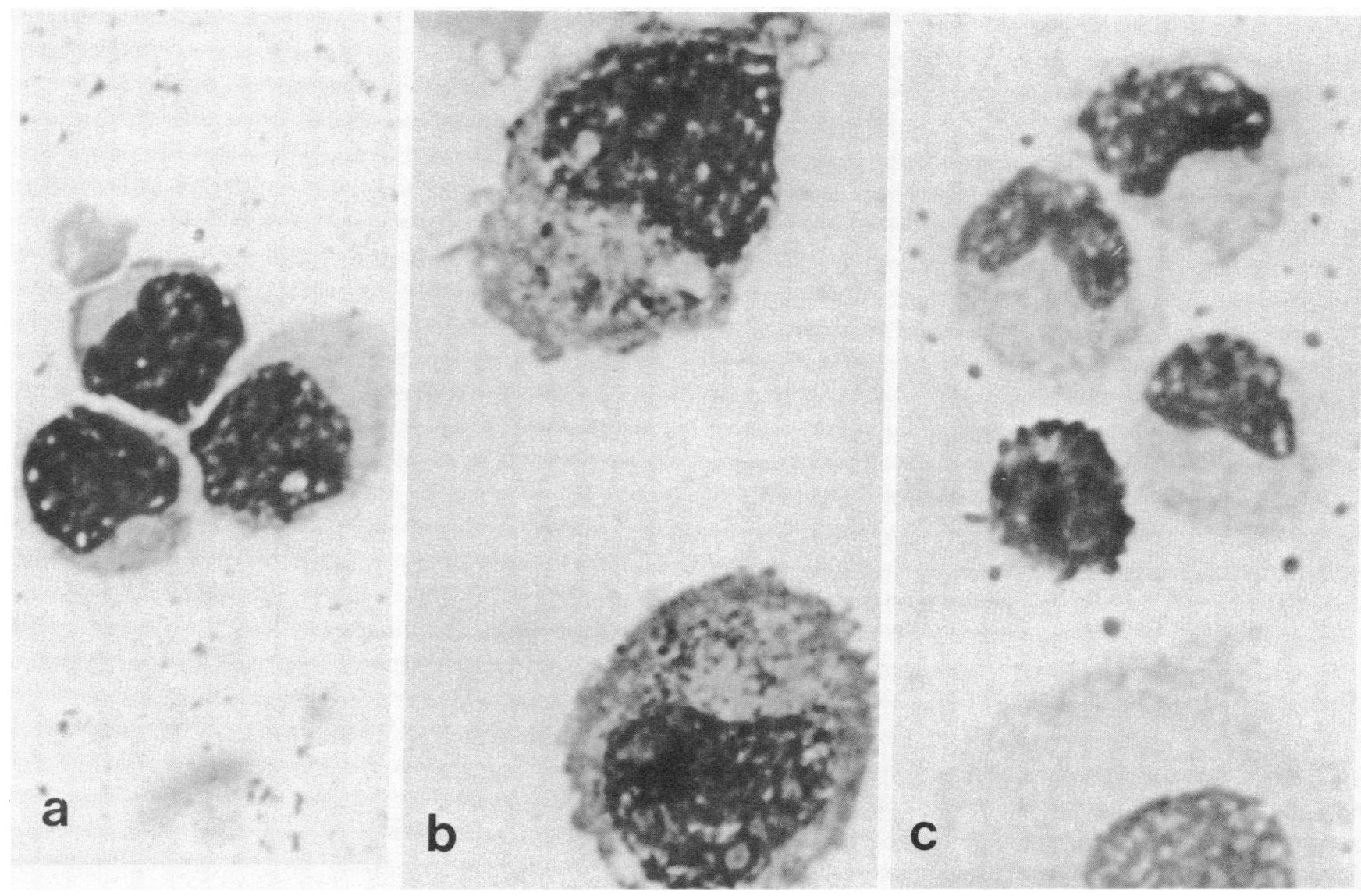

Figure 1. Differentiation of LDBM cells cultured for $96 \mathrm{~h}$ in HPCM. Photomicrographs $(\times 1250)$ of $(a)$ lymphoid-appearing surface immunoglobulin negative cells at the start of the culture; (b) progranulocytes predominating after $24 \mathrm{~h}$ of culture (note the characteristic progranulocytic granules); (c) nonmitotic metamyelocyte and band stage of differentiation that predominated after $96 \mathrm{~h}$ of culture.

up to $72 \mathrm{~h}$ and a decline thereafter. Cells that were not exposed to HPCM did not show a significant change in uptake. This 24fold increase by $72 \mathrm{~h}$ was observed consistently when the LDBM

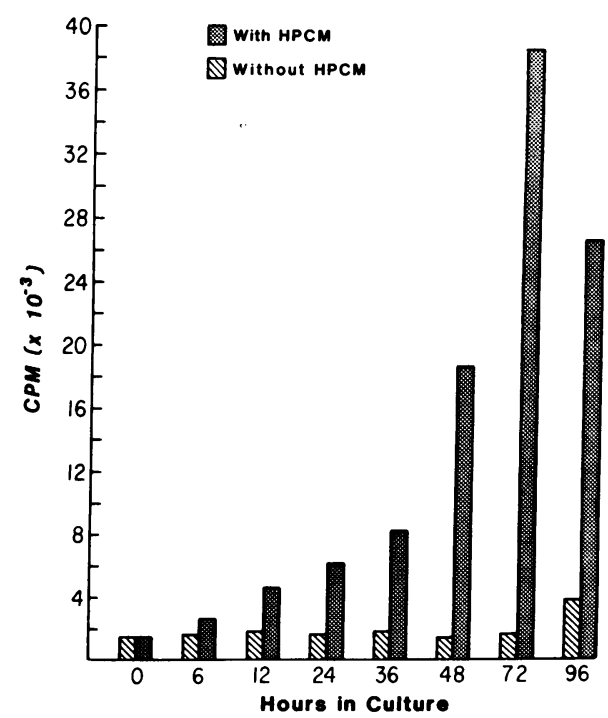

Figure 2. Proliferative response of HPCM-stimulated LDBM cells. The incorporation of $\left[{ }^{3} \mathrm{H}\right]$ thymidine at various times after the stimulation of LDBM cells with HPCM. Triplicate cultures were assayed for each time point. A representative experiment is shown. A similar pattern of incorporation has been seen in all experiments. cells were cultured in the presence of HPCM but did not occur in the absence of HPCM. A cytofluorographic phenotype analysis showing the temporal increase in myeloid cells after HPCM stimulation of LDBM cells is seen in Fig. 3. OKM1-positive cells increased sevenfold by 96 h. OKT3-positive cells did not increase during the culture period. OKM1-positive cells reflect largely the cells of neutrophilic lineage because the majority of cells were chloroacetate esterase-positive. Specifically, there was a sevenfold increase in chloroacetate esterase positive cells by $96 \mathrm{~h}$, whereas monocyte-specific esterase positive-cells declined (data not shown). Therefore, the response of LDBM cells to HPCM was largely granulocytic.

To define the differentiation stages in vitro, differential cell counts were performed on Wright's stained cytocentrifuged slides. As shown in Fig. $4 a$, there was a wave of maturation from primarily lymphoid appearing cells to metamyelocytes and band forms after $96 \mathrm{~h}$. Peaks of myeloblasts were noted at 12 $\mathrm{h}$, progranulocytes at $24 \mathrm{~h}$, and myelocytes after $72 \mathrm{~h}$. The cells cultured in the absence of HPCM (Fig. $4 b$ ) showed a similar pattern of maturation (there were more mononuclear phagocytes) without detectable proliferation. We cannot state that this pattern of maturation was wholly independent of CSA, however; it could be due to the production of small amounts of CSA by residual monocytes and $T$ cells $(23,24)$.

C-myc transcripts during HPCM-stimulated myeloid cell differentiation. Northern blot hybridization analysis with a cDNA probe (33) of the human c-myc mRNA revealed a transcript of $\sim 2.4$ kilobases $(\mathrm{kb})$ in cells exposed to HPCM for $24 \mathrm{~h}$ (Fig. 5 


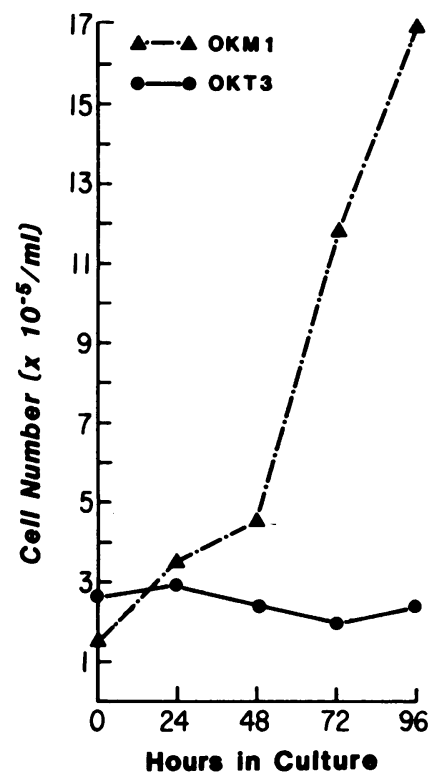

a). This transcript was comparable in size to c-myc transcripts found in HL-60 cells (Fig. $5 a$ ) and probably represents a normally spliced c-myc mRNA species $(16,17,34)$ transcribed from the 5.2-kb c-myc gene. Using these techniques it was not possible to detect which of the two promotors (35) was utilized in these cells. The number of c-myc transcripts returned to background level, after $48 \mathrm{~h}$. The Northern blot results, which indicate a peak of c-myc transcripts after $\sim 24 \mathrm{~h}$ of culture in the presence of HPCM, were confirmed in five separate dot-blot analyses as well (Fig. $5 b$ ).

To define more exactly the time at which transcripts begin to increase, the cells were harvested at 12-h intervals for up to $48 \mathrm{~h}$ and mRNA was analyzed by dot-blot technique. As shown in Fig. $5 b$ c-myc transcripts increase between 12 and $24 \mathrm{~h}$ after exposure to CSA and decline to background levels before 36 h. To show further that the differentiated granulocytes do not express the c-myc gene, we obtained a pure population of granulocytes from peripheral blood and analyzed for the c-myc transcripts. As predicted, we did not detect any c-myc mRNA transcripts (data not shown). Cells cultured in the absence of HPCM were also examined. Even though we observed cell maturation, as shown in Fig. $4 b$, we did not see any change in the expression of the c-myc gene. However, our assays may not be sensitive enough to detect small changes in c-myc mRNA content.

To control for the relative amount of mRNA in each sample, aliquots of mRNA were analyzed for $\gamma$-actin mRNA by dotblot assay. A pBR322 clone containing a 700-base-pair (bp) HindIII-BamH 1 insert of the $3^{\prime}$ untranslated portion of human $\gamma$-actin (36) was used. As shown in Fig. $5 c, \gamma$-actin mRNA remains nearly constant relative to total RNA throughout the course of HPCM-stimulated myeloid differentiation. This was confirmed by densitometric scanning of the autoradiogram (data not shown). As a negative control, we used a pBR322 clone containing a 4.4-kb Pst 1 insert of the human $\beta$-globin probe. We did not detect any hybridization at any harvest time point even after prolonged autoradiography (data not shown).

Because some of our target populations had as many as $11 \%$ $T$ lymphocytes and $16 \%$ monocytes at the time of exposure to HPCM, it was necessary to examine c-myc gene expression in $T$ lymphocytes and monocytes from normal marrow after ex-

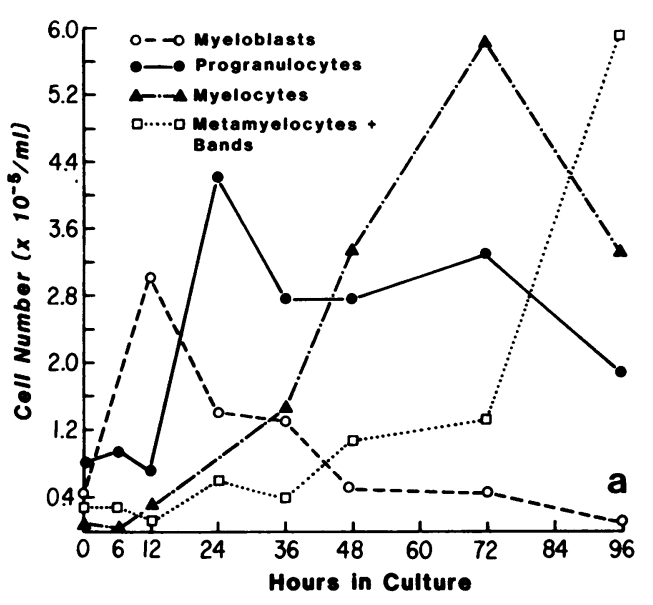

:

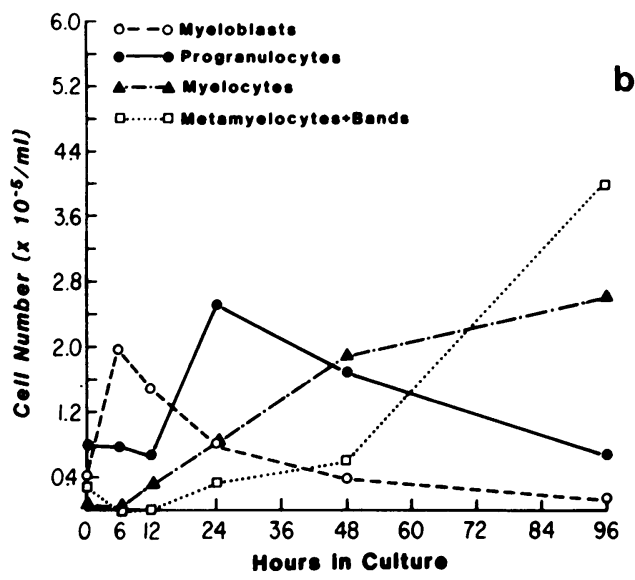

Figure 4. Differentiation of HPCM-stimulated LDBM cells. (a) Bone marrow cells exposed to HPCM were cytocentrifuged on slides at 0,6 , $12,24,36,48,72$, and $96 \mathrm{~h}$, for Wright-stained differential counts. A wave of maturation was observed from initially lymphoid-appearing and blast cells to metamyelocytes and bands after $96 \mathrm{~h}$. Peaks of myeloblasts at $12 \mathrm{~h}$, progranulocytes at $24 \mathrm{~h}$, and myelocytes after $72 \mathrm{~h}$ can be noted. A representative experiment is shown. Similar results have been obtained in additional experiments. (b) Same as in $a$, but the cells were not exposed to HPCM.

posure to HPCM. Accordingly, we recovered T lymphocytes from the sheep erythrocyte rosettes by hypotonic lysis and recovered monocytes by adherence to serum-coated dishes ( $>92 \%$ monocytes) $(23,24)$. These cells were exposed to HPCM for 24 $h$ and probed for c-myc transcripts. With neither cell type did HPCM induce c-myc gene expression (Fig. $5 b$ ), nor did a mixture of monocytes and $T$ cells (data not shown). In view of these results and the findings that $T$ cells and mononuclear phagocytes declined in number in HPCM-stimulated cultures, we conclude that c-myc expression seen after $24 \mathrm{~h}$ of exposure to HPCM was in actively proliferating granulocyte precursors.

$C$-myc gene is not amplified during normal myeloid cell differentiation. In the progranulocytic cell line HL-60, the c-myc gene is amplified 16-32-fold $(18,19)$. It has been suggested that c-myc amplification may occur in other nonmalignant myeloid cells, and thus may represent a normal event in myeloid differentiation $(18,19)$. We sought, therefore, to measure the abundance of c-myc gene copies in normal cells as a function of differentiation stage. $\mathrm{C}$-myc gene sequences in normal granu- 

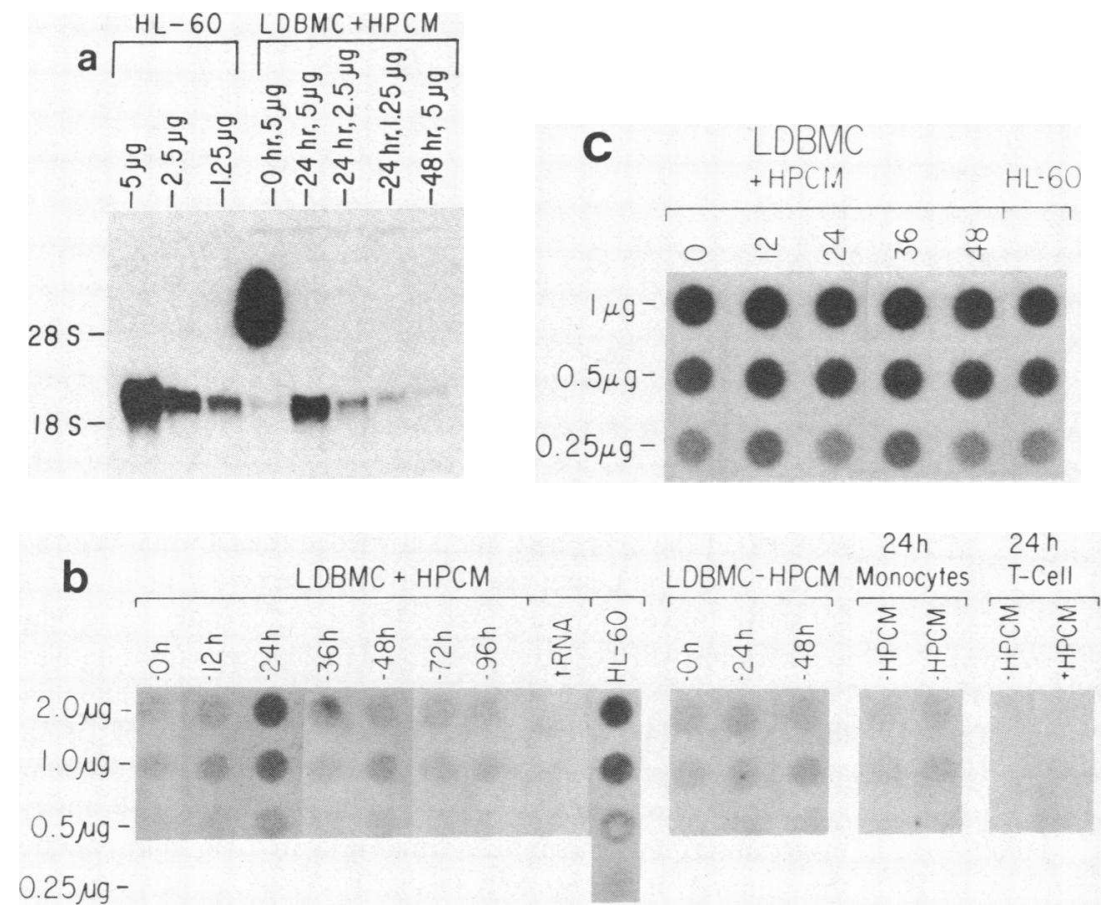

Figure 5. C-myc gene expression in HPCM-stimulated differentiation of LDBM cells. (a) Northern blot analysis of c-myc RNA transcripts in poly (A)-containing RNA from cells harvested at various times of culture with HPCM. Poly (A)containing RNA was fractionated on a $1 \%$ agarose gel, transferred to Genescreen membranes, and hybridized with a ${ }^{32} \mathrm{P}$-labeled cDNA probe of the human c-myc gene. The spot on top of the autoradiogram is a hybridization artifact. $(b)$ Poly (A)-containing RNA from HPCM-stimulated LDBM cells, and from adherent cells and T-lymphocytes with or without 24 h-exposure to HPCM, were dot-blotted onto Genescreen membranes and hybridized with a probe specific for the second and third exons of c-myc. The dot blot shown was a representative of four separate experiments. (c) Same as in $b$, except for hybridization with a probe specific for $3^{\prime}$ untranslated region of $\boldsymbol{\gamma}$-actin gene. lopoietic cells were detected in the unfractionated DNA isolated from the nuclei of cells harvested over a 96-h period at 12-h intervals by the dot-blot technique. A representative experiment is shown in Fig. $6 a$. Autoradiograms were scanned for the changes in the intensity of the dots that would indicate changes in the abundance of c-myc sequences. The intensity of the spots was 14-16 times lower than for the DNA from the same number of HL-60 cells (Fig. 6 b). The results indicate that gene copy number is stable at each developmental stage.

Levels of c-myc transcripts in normal cells and HL-60 cells. We have compared the levels of c-myc expression in LDBM cells-after $24 \mathrm{~h}$ HPCM stimulation-with the level of c-myc expression in HL-60 cells. As shown in Table I, we noted that for a given amount of mRNA loaded on the blot, c-myc RNA derived from HL-60 cells represented $150 \%$ of that derived from normal LDBM cells harvested at $24 \mathrm{~h}$. In addition, mRNA yield from HL- 60 cells was $166 \%$ that of normal LDBM cells after 24-h culture in HPCM. Therefore, on a cell-for-cell basis, c-myc RNA content of HL-60 cells is 2.5 -fold higher than in LDBM cells. We do not yet know the cell type(s) transcribing c-myc in our system. We can surmise, however, that cells more differentiated than progranulocytes do not because c-myc is fully repressed in cultures in which such cells predominate. Therefore, we suspect that cell type(s) including early progranulocytes or their progenitors are those which transcribe c-myc.

Stability of c-myc transcripts in normal cells and $H L-60$ cells. As shown in Fig. 7, upon exposure of cells to actinomycin D for $30 \mathrm{~min}$, c-myc mRNA content was dramatically reduced in both HL-60 and normal cells while $\boldsymbol{\gamma}$-actin remained unchanged (Fig. 7) in LDBM cells. Our estimate of the half-life of c-myc transcripts in HL-60 cells is virtually identical to the estimates of Dani et al. (31). This suggests that our particular subclones are similar in this regard. However, we do anticipate that other subclones might behave differently because a variety of HL-60 sub lines are known to differ in c-myc expression (35, 37-39).

C-myc transcripts in primary cultures of leukemic cells. In
HPCM-stimulated normal LDBM cells, the number of c-myc transcripts increase approximately threefold by day 1 and is followed by a consistent decline to undetectable levels by day 5 (Table II). Unlike normal LDBM cells in which c-myc transcripts decline over time, acute leukemic cells, which failed to differentiate to mature neutrophils in vitro, exhibited high levels of c-myc transcripts throughout the culture period (Table II).

\section{Discussion}

Although c-myc expression has been found in certain neoplastic cell lines $(40,41)$ and in most freshly obtained malignant tissues studied to date (42), expression of this cellular oncogene has been clearly demonstrated in certain proliferating normal cells as well $(3,6-10)$. Thus, it is generally acknowledged that c-myc expression per se is inadequate to account for the assumption of the neoplastic phenotype $(12,13)$. Our observation that normal primitive myeloid precursor cells express c-myc also supports this view. Certain other observations have been interpreted as suggesting that it may be the inappropriateness of c-myc activation that plays a role in the development or maintenance of the neoplastic phenotype. For example, the integration of avian leukosis virus occurs close to and on the $5^{\prime}$ side of c-myc in avian B cell lymphomas (43). In addition, c-myc is regularly translocated close to either the heavy or light-chain immunoglobulin genes, and in these cells c-myc is actively expressed (15). Finally, amplification of c-myc gene has been documented in both nonhematopoietic $(41)$ and hematopoietic $(18,19)$ tumor cell lines. The HL-60 progranulocytic leukemia cell line is one in which the c-myc gene is actively both expressed and amplified. Our studies were designed, in part, to provide contextual information relevant to c-myc amplification and expression in HL-60 cells.

Conceptually, linkage of c-myc expression to both gene amplification and to the neoplastic phenotype in malignant cells 

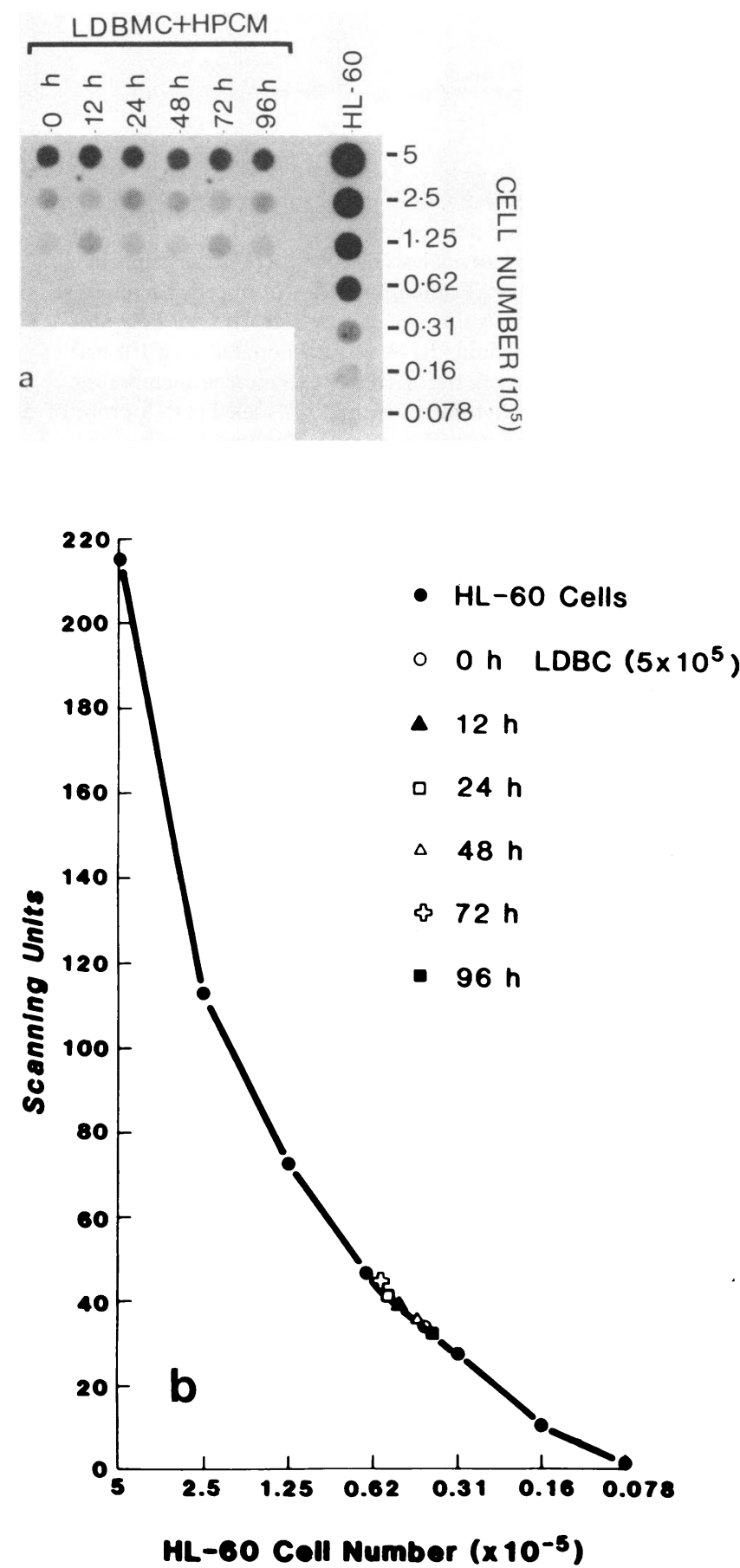

Figure 6. DNA dot blot of HPCM-stimulated LDBM cells. (a) Cellular DNA isolated from nuclei of HPCM-stimulated LDBM cells at 0 , $12,24,48,72$, and $96 \mathrm{~h}$ as outlined in the experimental procedures, were dot-blotted on Genescreen-plus membranes and hybridized with a probe specific for second and third exons. HL-60 DNA was also analyzed similarly. We found that HL-60 cells had 14-16-fold higher gene copies per cell than did normal cells and that gene amplification did not occur in the normal cells. (b) The autoradiogram (shown in $a$ ) was scanned and the scanning units were plotted against the number of HL-60 cells used per time point. The readings obtained for LDBM cells $\left(5 \times 10^{5}\right)$ were plotted on the curve obtained for HL-60. The relative increase of c-myc gene copies in HL-60 cells was calculated as the ratio of the number of LDBM cells used to the number of HL-60 cells giving similar densitometric reading.
Table I. Relative Levels of c-myc in $H L-60$ and Normal Myeloid Progenitor Cells

\begin{tabular}{llll}
\hline Cells & $\begin{array}{l}\text { Total RNA } \\
\text { yield }\end{array}$ & $\begin{array}{l}\text { Relative c-myc } \\
\text { RNA level } \\
\text { (constant } \\
\text { RNA) }\end{array}$ & $\begin{array}{l}\text { Relative increase } \\
\text { of c-myc RNA } \\
\text { (per cell) }\end{array}$ \\
\hline & $\mu g / 10^{7}$ cells & & \\
$\begin{array}{l}\text { HL-60 } \\
\text { 24-h HPCM-stimulated } \\
\text { LDBM cells }\end{array}$ & $7.25( \pm 1.5)$ & 1.5 & 2.5 \\
\hline
\end{tabular}

requires, at the very least, the knowledge that normal cells at the same developmental stage exhibit neither gene amplification nor active c-myc expression. Accordingly, in this study, we sought to determine whether primitive granulopoietic cells from human bone marrow normally express c-myc. Our results indicate that they do after $24 \mathrm{~h}$ of culture in the presence of CSA (Fig. 5). In addition, c-myc gene copy number is not increased at $24 \mathrm{~h}$ or at any other time before or after $24 \mathrm{~h}$ (Fig. 6). Moreover, the cmyc transcript numbers in normal cells at $24 \mathrm{~h}$ approximate those found in HL-60 cells (Table I). There are at least two possible explanations of the latter finding. First, the HL-60 cells with 16-fold amplified gene copies might transcribe each copy at a normal rate, producing 16 -fold increased transcripts which are then more rapidly degraded than are normal transcripts. Because our experiments on myc RNA turnover (Fig. 7) indicate otherwise, we subscribe to the alternative view that the amplified copies are, relative to the single copy in normal cells at $24 \mathrm{~h}$ of culture, transcriptionally silent. Such findings are not entirely without precedent. Recently, normal placental cytotrophoblasts were found to contain as much c-myc RNA as did cells of a malignant cell line (COLO 320 HSR) harboring 16-32-fold amplified c-myc genes (10).

Although it is of interest that the predominant cell after 24 $h$ of culture is the progranulocyte, we cannot yet directly compare these progranulocytes to the HL-60 cells because we do not yet know which cell types transcribe c-myc. We do believe, however, that cells more differentiated than progranulocytes do not tran-

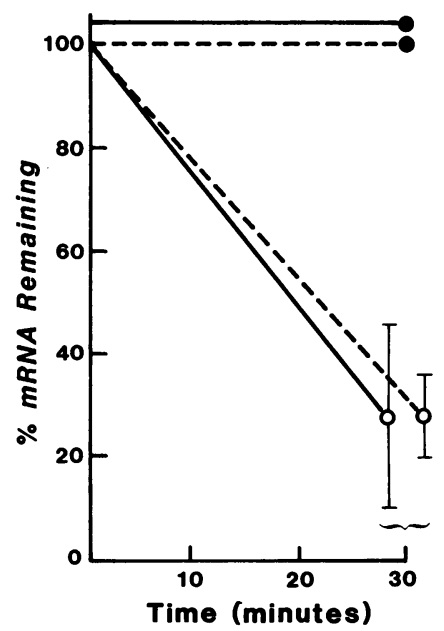

Figure 7. mRNA degradation rates in normal (-) and HL60 cells (- - ). HL-60 cells and LDBM after $24 \mathrm{~h}$ of culture were cultured for $30 \mathrm{~min}$ in $5-$ $10 \mu \mathrm{g} / \mathrm{ml}$ actinomycin $\mathrm{D}$. mRNA was obtained from cells, dot-blotted on Genescreen membranes, and hybridized with labeled $\gamma$-actin $(\bullet)$ or c-myc (O) probes. mRNA content at 30 min was quantitated by densitometric scanning of autoradiograms and survival was expressed as the percentage of the actinomycin $\mathrm{D}$ controls. Results shown are mean \pm SD from values obtained in three (normal) and four (HL-60) separate experiments. 
Table II. Comparison of Temporal c-myc Expression in Normal and Leukemic Myeloid Cells

\begin{tabular}{lllllllll}
\hline & \multicolumn{1}{c}{ c-myc transcripts } \\
\cline { 2 - 7 } Cells & Days & 0 & 1 & 2 & 3 & 4 & 5 \\
\hline $\begin{array}{l}\text { LDBM cells }(n=5) \\
\begin{array}{c}\text { Acute myeloblastic } \\
\text { leukemia }(n=3)\end{array}\end{array}$ & \pm & +++ & + & \pm & \pm & - \\
$\begin{array}{c}\text { Acute promyelo- } \\
\text { cytic leukemia* } \\
(n=1)\end{array}$ & ++ & +++ & +++ & +++ & NT§ & NT \\
$\quad$ & ++ & ++ & ++ & ++ & NT & NT
\end{tabular}

* The patient was on retinoic acid therapy when the sample was taken.

¥ The autoradiograms were scanned densitometrically and the lowest reading was assigned - and the highest +++++ .

$\S$ Not tested.

scribe c-myc because, when such cells predominated in vitro, transcription was fully repressed. It is conceivable that the CSAsensitive clonogenic progenitor cell, the colony-forming unit/ granulocyte-macrophage, most actively transcribes c-myc. Prior work in HL-60 cells in which c-myc transcription was found to decrease when the cells were induced to differentiate (44) is compatible with the notion that c-myc activity is linked somehow to the maintenance of the neoplastic phenotype. An alternative point of view, one with which our observations are compatible, is that c-myc is simply transcribed in these cells because it normally transcribed in early progranulocytes or their progenitors and normally become quiescent when the cells differentiate further $(18,19,44)$. Only studies on c-myc expression in single cells can resolve the issue of whether transcription occurs only in a specific differentiation stage.

It is clear, however, that leukemic cells and normal cells differ substantially in their patterns of c-myc expression. Specifically, leukemic cells fail to repress myc expression normally. Although it has been proposed that c-myc mRNA inactivation may be a mechanism by which gene expression is regulated in certain human cell lines, including HL-60 cells (31), we found no differences in mRNA degradation between the normal and HL-60 cells; mRNA was rapidly degraded in both. The analysis of myc RNA degradation rates was done using dot-blot analyses and, in one instance, Northern blot analysis (Fig. 7). C-myc is known to have two separate initiation sites. Two transcripts have been identified in many normal cells (45). We do not yet know which transcripts are found in all normal cells. Nor do we know whether differential transcript degradation occurs. Nevertheless, our observations on degradation rates are most compatible with the notion that regulation of c-myc expression in normal and leukemic cells differs largely in the mechanisms by which gene transcription is repressed. Whether the failure of any cell to repress c-myc during growth and differentiation is a cause or effect of the neoplastic phenotype remains to be determined.

In summary, despite the similarities between them, there are two clear differences between normal and leukemic cells $v i s-\grave{a}$ vis c-myc expression. First, HL-60 cells proliferate autonomously and express c-myc constitutively, that is, without requiring exposure to CSA, whereas c-myc expression can only be induced in normal cells by exposure to CSA. Second, an abnormality shared by HL-60 cells and primary cultures of freshly obtained leukemic cells is that whereas normal cells exposed to CSA invariably repress c-myc after $36 \mathrm{~h}$ in culture, leukemic cells fail to do so even after $5 \mathrm{~d}$. Therefore, even if c-myc ultimately proves not to be causally linked with the leukemic phenotype, its expression may prove to be a valuable marker of a primitive developmental stage, and failure to supress transcription in vitro may prove to be a reliable marker of a leukemic phenotype. Studies addressing the mechanisms by which normal myeloid cells repress $c-m y c$ should provide important insights on the regulatory abnormalities of gene expression that underlie the behavior of myeloid leukemic cells.

\section{Acknowledgments}

We are grateful to Drs. Jean-Francoise Conscience, Richard Jones, Michael Litt, David Kabat, Leslie Hallick, Demetrios Rigas, De-Ann Pillers, and Michael Riscoe for their critical suggestions.

This work was supported in part by grant from the National Cancer Institute (CA36306), the Medical Research Foundation of Oregon, The Higgins Trust, and The Jackson Foundation, Portland, Oregon. Dr. Gowda is a recipient of fellowship from the N.L. Tartar Trust and the Leukemia Association of Oregon Inc.

\section{References}

1. Bishop, J. M. 1983. Cellular oncogenes and retroviruses. Annu. Rev. Biochem. 52:301-354.

2. Cooper, G. M. 1982. Cellular transforming genes. Science (Wash. DC). 218:801-806.

3. Muller, R., and I. M. Verma. 1984. Expression of cellular oncogenes. Curr. Top. Microbiol. Immunol. (Retroviruses 3) 112:73-115.

4. Doolittle, R. F., M. W. Hunkapiller, L. E. Hood, S. G. Devare, K. C. Robbins, S. A. Aaronson, and H. N. Antoniades. 1983. Simian sarcoma virus onc gene, $v$-sis, is derived from the gene (or genes) encoding a platelet-derived growth factor. Nature (Lond.). 221:275-277.

5. Downward, J., Y. Yarden, E. Mayes, G. Scrace, N. Totty, P. Stockwell, A. Ullrich, J. Schlessinger, and M. D. Waterfield. 1984. Close similarity of epidermal growth factor receptor and v-erb-B oncogene protein sequences. Nature (Lond.). 302:521-526.

6. Goyette, M., C. J. Petropoulos, P. R. Shank, and N. Fausto. 1984. Regulated transcription of c-Ki-ras and c-myc during compensatory growth of rat liver. Mol. Cell. Biol. 4:1493-1498.

7. Bering, H. A., S. Duttagupta, and P. Lebowitz. 1984. Proto-oncogene expression during erythroid proliferation. Clin. Res. 32:304A. (Abstr.)

8. Keath, E. J., A. Kelekar, and M. D. Cole. 1984. Transcriptional activation of the translocated c-myc oncogene in mouse plasmacytomas: similar RNA levels in tumor and proliferating normal cells. Cell. 37: 521-528.

9. Kelly, K., B. H. Cochran, C. D. Stiles, and P. Leder. 1983. Cell specific regulation of the c-myc gene by lymphocyte mitogens and platelet-derived growth factor. Cell. 35:603-610.

10. Pfeifer-Ohlsson, S., A. S. Goostin, J. Rydnert, T. Wahlstrom, L. Bjersing, D. Stehelin, and R. Ohlsson. 1984. Spatial and temporal pattern of cellular myc oncogene expression in developing human placenta: implications for embryonic cell proliferation. Cell. 38:585-596.

11. Hann, S. R., and R. N. Eisenman. 1984. Protein encoded by the human c-myc oncogene: differential expression in neoplastic cells. $\mathrm{Mol}$. Cell. Biol. 4:2486-2497.

12. Land, H., L. F. Parada, and R. A. Weinberg. 1983. Cellular oncogenes and multistep carcinogenesis. Science (Wash. DC). 222:771778.

13. Stewart, T. A., P. K. Pettengale, and P. Leder. 1984. Spontaneous mammary adenocarcinomas in transgenic mice that carry and express MTV/myc fusion genes. Cell. 38:627-637. 
14. Persson, H., L. Hennighausen, R. Taub, W. Degrado, and $P$. Leder. 1984. Antibodies to human c-myc oncogene product: evidence of an evolutionarily conserved protein induced during cell proliferation. Science (Wash. DC). 225:687-693.

15. Leder, P., J. Battey, G. Lenoin, C. Moulding, W. Murphy, H. Potter, T. Stewert, and R. Taub. 1983. Translocations among antibody genes in human cancer. Science (Wash. DC). 222:765-771.

16. Erickson, J., A. Ar-Rushdi, H. L. Drwinga, P. C. Nowell, and C. M. Croce. 1983. Transcriptional activation of the translocated c-myc oncogene in Burkitt lymphoma. Proc. Natl. Acad. Sci. USA. 80:820824.

17. Maguire, R. T., T. S. Robins, S. S. Thorgeirsson, and C. A. Heilman. 1983. Expression of cellular c-myc and mos genes in undifferentiated B cell lymphomas of Burkitt and non-Burkitt types. Proc. Natl. Acad. Sci. USA. 80:1947-1950.

18. Collins, S., and M. Groudine. 1982. Amplification of endogenous c-myc-related DNA sequences in a human myeloid leukemia cell line. Nature (Lond.). 298:679-681.

19. Dalla-Favera, R., F. Wong-Staal, and R. Gällo. 1982. Onc gene amplification in promyelocytic cell line HL-60 and primary leukemic cells of the same patient. Nature (Lond.). 299:61-63.

20. Campisi, J., H. E. Gray, A. B. Pardee, M. Dean, and G. E. Sonenshein. 1984. Cell-cycle control of c-myc but not c-ras expression is lost following chemical transformation. Cell. 36:241-247.

21. Coll, J., S. Saule, P. Martin, M. B. Raes, C. Lagrou, T. Graf, H. Beug, I. E. Simon, and D. Stehelin. 1983. The cellular oncogenes c-myc, c-myb, and c-erb are transcribed in defined types of avian hematopoietic cells. Exp. Cell Res. 149:151-162.

22. Boyüm, A. 1976. Isolation of lymphocytes, granulocytes and macrophages. Scand. J. Immunol. 5(Suppl. 5):9-15.

23. Bagby, G. C., V. A. Rigas; R. M. Bennett, A. A. Vandenbark, and H. S. Garewal. 1981. Interaction of lactoferrin, monocytes, and Tlymphocyte subsets in the regulation of steady-state granulopoiesis in vitro. J. Clin. Invest. 68:56-63.

24. Bagby, G. C., E. McCall, and D. A. Layman. 1983. Regulation of colony stimulating activity production: interaction of fibroblasts, mononuclear phagocytes, and lactoferrin. J. Clin. Invest. 71:340-344.

25. Julius, M. H., E. Simpson, and L. A. Herzenberg. 1973. A rapid method for the isolation of functional thymus-derived murine lymphocytes. Eur. J. Immunol. 3:645-650.

26. Kumagai, K., K. Itoh, S. Hinuma, and M. Tada. 1979. Pretreatment of plastic dishes with fetal calf serum. A simple method for macrophage isolation. J. Immunol. Methods. 29:17-25.

27. Schlunk, T., and M. Schleyer. 1980. The influence of culture conditions on the production of colony-stimulating activity by human placenta. Exp. Hematol. 8:179-184.

28. Maniatis, T., E. F. Fritsch, and J. Sambrook. 1982. Molecular cloning: a laboratory manual. Cold Spring Harbor Laboratory Press, Cold Spring Harbor, NY. 194-195.

29. Aviv, H., and P. Leder. 1972. Purification of biologically active globin messenger RNA by chromatography on oligothymidylic acid-cellulose. Proc. Natl. Acad. Sci. USA. 69:1408-1412.

30. Meinkoth, J., and G. Wahl. 1984. Hybridization of nucleic acids immobilized on solid supports. Anal. Biochem. 138:267-284.
31. Dani, C. H., J. M. Blanchard, M. Piechaczyk, S. E. Sabouty, L. Marty, and P. Jeatnteur. 1984. Extreme instability of myc mRNA in normal and transformed human cells. Proc. Natl. Acad. Sci. USA. 81: 7046-7050.

32. Burgess, A. W., E. M. A. Wilson, and D. Metcalf. 1977. Stimulation by human placental conditioned medium of hematopoietic colony formation by human marrow cells. Blood. 49:573-583.

33. Watt, R., L. W. Stanton, K. B. Marcu, R. C. Gallo, C. M. Croce, and G. Rovera. 1983. Nucleotide sequence of cloned cDNA of human c-myc oncogene. Nature (Lond.). 303:725-728.

34. Adams, J. M., S. Gerondakis, E. Webb, L. M. Corcoran, and S. Cory. 1983. Cellular myc oncogene is altered by chromosome translocation to an immunoglobulin locus in murine plasmacytomas and is rearranged similarly in human Burkitt lymphomas. Proc. Natl. Acad. Sci. USA. 80:1982-1986.

35. Watt, R., K. Nishikura, J. Sorrentino, A. Ar-Rushdi, C. M. Croce, and $G$. Rovera. 1983. The structure and nucleotide sequence of the 5 end of the human c-myc oncogene. Proc. Natl. Acad. Sci. USA. 80: 6307-6311.

36. Ponte, P., P. Gunning, H. Blau, and L. Kedes. 1983. Human actin genes are single copy for $\alpha$-skeletal and $\alpha$-cardiac actin but multicopy for $\beta$ - and $\gamma$-cytoskeletal genes: 3'untranslated regions are isotype specific but are conserved in evolution. Mol. Cell. Biol. 3:1783-1791.

37. Graham, S. V., R. W. Tindle, and G. D. Birnie. 1985. Variation in myc gene amplification and expression in sublines of HL-60 cells. Leuk. Res. 9:239-247.

38. McCarthy, D. M., F. V. Rassool, J. M. Goldman, S. V. Graham, and G. D. Birnie. 1984. Genomic alterations involving the c-myc protooncogene locus during the evolution of a case of chronic granulocytic leukemia. Lancet i:1362-1365.

39. Nishikura, K., S. Goldflam, and G. A. Vuocolo. 1985. Accurate and efficient transcription of human c-myc genes injected into Xenopus laevis oocytes. Mol. Cell. Biol. 5:1434-1441.

40. Croce, C. M., and D. Kozbor. 1984. Amplification of the c-myc oncogene in one of five human breast carcinoma cell lines. Cancer Res. 44:438-441.

41. Little, C. D., M. M. Nau, D. N. Carney, A. F. Gazdar, and J. D. Minna. 1983. Amplification and expression of the c-myc oncogene in human lung cancer cell lines. Nature (Lond.). 306:194-196.

42. Slamon, D. J., J. B. de Kermon, I. M. Verma, and M. J. Cline. 1984. Expression of cellular oncogenes in human malignancies. Science (Wash. DC). 224:256-264.

43. Hayward, W. S., B. G. Neel, and S. M. Astrin. 1981. Activation of cellular oncogenes by promotor insertion in ALV-induced lymphoid leukosis. Nature (Lond.). 296:475-479.

44. Reitsma, P. H., P. G. Rothberg, S. M. Astrin, J. Trial, Z. BarShavit, A. Hall, S. L. Teitelbaum, and A. J. Kahn. 1983. Regulation of c-myc gene expression in HL-60 leukemia cells by a vitamin D metabolite. Nature (Lond.). 306:492-494.

45. Stewart, T. A., A. R. Bellve, and P. Leder. 1984. Transcription and promotor usage of the myc gene in normal somatic and spermatogenic cells. Science (Lond.). 226:707-710. 